\title{
Anxiety and Family Support on Infected TORCH Patients
}

\author{
Eirene Shinta Valevi, Lina Handayani
}

Public Health Faculty, Universitas Ahmad Dahlan, Yogyakarta, Indonesia

\begin{tabular}{l} 
Article Info \\
\hline Article history: \\
Received Sept 28, 2014 \\
Revised Oct 20, 2014 \\
Accepted Nov 22, 2014 \\
\hline
\end{tabular}

Keyword:

Anxiety

Family Support

Patient

TORCH

\begin{abstract}
TORCH is an acronym of Toxoplasmosis, Rubella, Cytomegalovirus, and Herpes simplex diseases. These diseases can cause abnormalities in the brain, impaired psychomotor and cognitive function, fertility, miscarriage, birth defects, etc. Infected TORCH patient tend to experience anxiety and worry after discovering he/she was diagnosed infected TORCH. For infected TORCH patient, family support is external factors that influence the treatment TORCH process. The purpose of this study was to describe the anxiety and family support on infected TORCH patients in Klinik Utama Thursina Husada, Yogyakarta, Indonesia. The design of this study was descriptive qualitative with case study approach. All subjects in this study had worries on costly medical expenses of TORCH. TORCH symptoms that asymptomatic made informants and family ever thought that it was a nonmedical disease. Each informant can overcome the anxiety that they face because of emotional support, esteem support, instrumental support, and informational support from family. Infected TORCH caused the patient had anxiety and worries. Family support was very helpful in the process of TORCH treatment.
\end{abstract}

Copyright (C) 2014 Institute of Advanced Engineering and Science. All rights reserved.

\section{Corresponding Author:}

Lina Handayani,

Public Health Faculty,

Universitas Ahmad Dahlan,

Jl. Prof.Dr. Soepomo, Janturan, Yogyakarta 55164, Indonesia.

Email: linafkm@gmail.com

\section{INTRODUCTION}

TORCH is a combination from four types of disease which are; Toxoplasmosis, Rubella, CMV, and Herpes Simplex. TORCH has spread all over the world. High prevalence of Toxoplasmosis mostly happens in the society who pets many cats and happens in where there are many rats or birds which can be the intermediary of the disease. Rubella epidemics mostly happen in spring season and most cases happen in kids and youth. CMV infection can be seen endemically and can appear anytime without being influenced by the season changes. Infection prevalence of the CMV is high in the developing country and most of the cases are in the middle-down class of society. High incidence of Herpes simplex could also be found in the low income society who lives in the crowded area [1].

TORCH disease often causes fertility in both male and female, strike all ages and sex. TORCH can also strike the brain which often cause headache symptoms, often cause a sore throat, prolonged flu, pain in muscles, joints, hips, legs, stomach and eyes, and so on [2]. Toxoplasma gondii (T. gondii), the source of TORCH disease can cause the abortion in pregnant women or the babies born with defects such as hydrocephalus and anencephaly [1]. TORCH infection can strike the whole body system, including organs of the central nervous system and peripheral which control the visual function, cardiovascular system, also body immune [3].

Not all of TORCH patients can adapt to cover the pressure that they are facing, which causes their psychic problems to appear and are hard to be solved which can also impact to their psychology. They tend to 
feel the negative impacts from their disease, such as high worry feeling when they notice that they are being infected. Concerns and supports from the family and special people are really important for them to adapt and face their disease [3]. The presence and helps from people like parents, partners, and friends can mean big for their health [4] and well-being in individuals [3].

\section{RESEARCH METHOD}

Design of this research was qualitative descriptive with the case study approach. Case study research is a study that explores a problem with a certain limitation, have a deep data collecting processed, and embedding various information sources. This research is being limited by time and place and the case that is being studied are in terms of: programs, events, activities, or individuals [5].

Data was collected by in-depth interview technique and in-depth interview observation which are the process to gain information by direct interview with the informants, with or without using the interview guidance, where the interviewers and informants are involved in long term social interaction. Observation is a method of collecting data process which is gained by observing the place, actors, activities, objects, actions, accidents or events, times, and feelings [5]. By using this qualitative research, the researcher hopes to get the information that is not only about the anxiety and supports from the families of the TORCH infected patients, but also the other things that are related with anxiety and supports from the families of the TORCH infected patients. With this qualitative resource also, the researcher hope to see the condition of the research subject by themselves, families, or even the related doctors.

The researcher did the research to individuals in range 15 - 30 years old, both the married and unmarried ones, and being infected in one and/or all kinds of TORCH diseases. There are 3 informants in this research. The variable of this research was the anxiety on infected TORCH patient and family support on infected TORCH patient. Data was analysed by using the semiotic content analysis system and triangulated. Content analysis system is the research technique that is used to reference the replicable and valid data in the related context. The researcher is looking for the irregular forms and patterns of the text and making a conclusion based on that irregular finding [6]. The stage we used to analyse our data was: 1) data organizing based on the interviews, observations, and triangulate; 2) case descriptions in each subject. This research was conducted in January 2014 to July 2014 at the Klinik Utama Thursina Husada, Godean, Yogyakarta. However, the minimum number of subjects can be the limitation of the study.

\section{RESULTS AND ANALYSIS}

\subsection{Results}

The researcher conducted observations and interviews with a number of informants, namely: P1 on 21 March 2014, P2 on 24 May 2014, and P3 on 25 May 2014. Triangulation was also done with the family of P1 and P2 (on 28 May 2014), and the family of P3 (on 25 May 2014). Triangulation through interviews was also done with a neurologist on 2 June 2014 and a psychiatrist on 25 July 2014, after the psychiatrist interviewed all the informants to measure their respective level of anxiety.

\subsubsection{Anxiety}

To measure the anxiety level of each informant, the researcher asked for assistance from a psychiatrist to measure it since the use of the HRS-A anxiety scale can only be performed by a psychiatrist or an expert in this field. According to the diagnosis of the psychiatrist, the anxiety level of P1 remains in a medium level, but P2 and P3 didn't had anxiety. Based on interviews with informants and triangulated, P1 experienced worries over whether the disease that P1 developed could be cured or not and its academic activities on campus. P2 and P3, who already married and have children under five, have worries if TORCH infects their children. All informants had worries about TORCH medical cost.

\subsubsection{Family Support}

There are four types of family support, namely emotional support, esteem support, instrumental support, and informational support. Here are the types of family support that each research subject obtained: 
Table 1. Type of Support Provided by the Research Subjects' Family

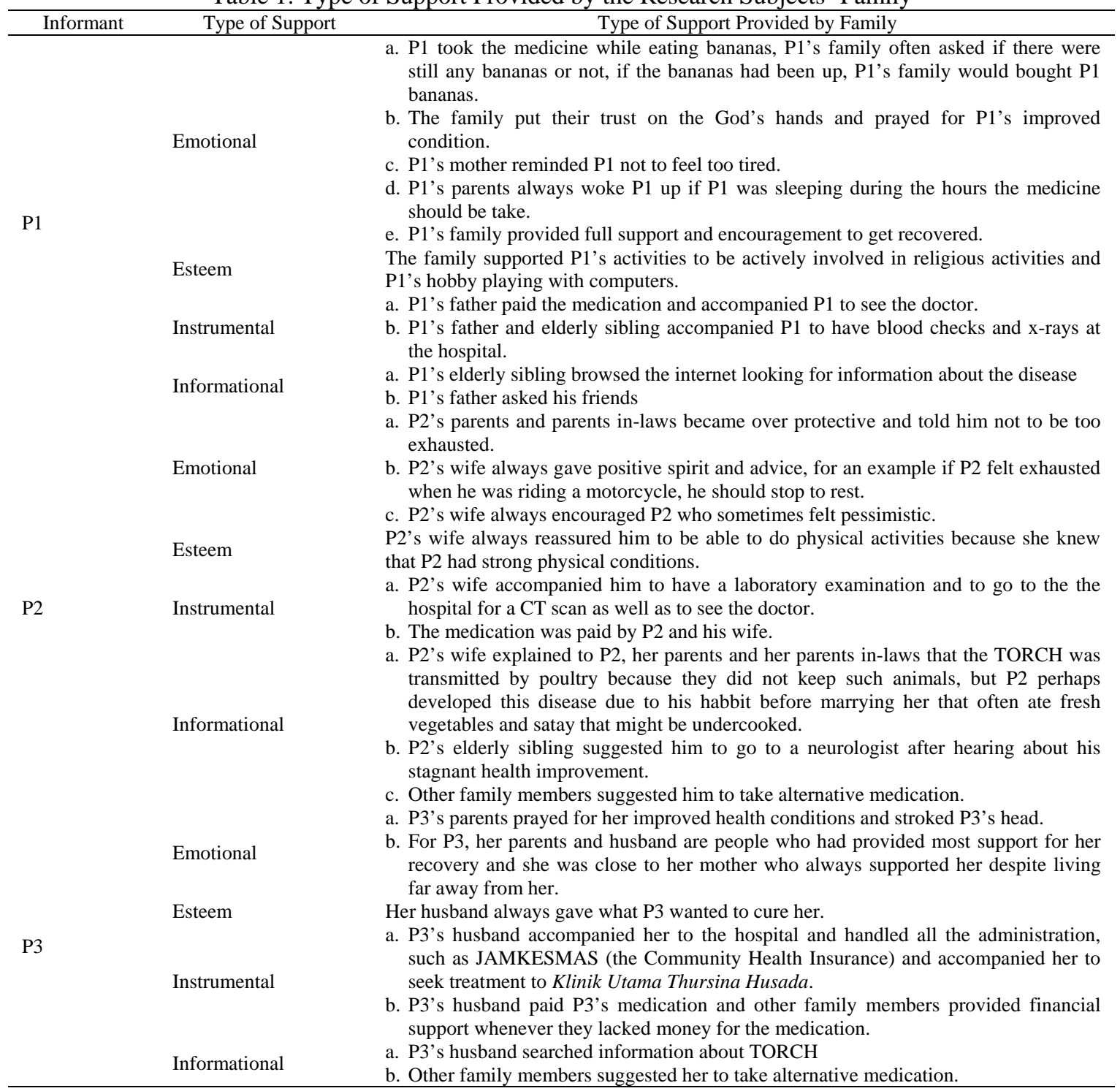

\subsection{Analysis}

This research was qualitative descriptive with the case study approach and analysed data by using the semiotic content analysis system and triangulated. The researcher conducted interviews with each informant and their own family as well as observations, then analyzed the case of each research subject with the following results: 
Table 2. Analysis of the Research Subjects

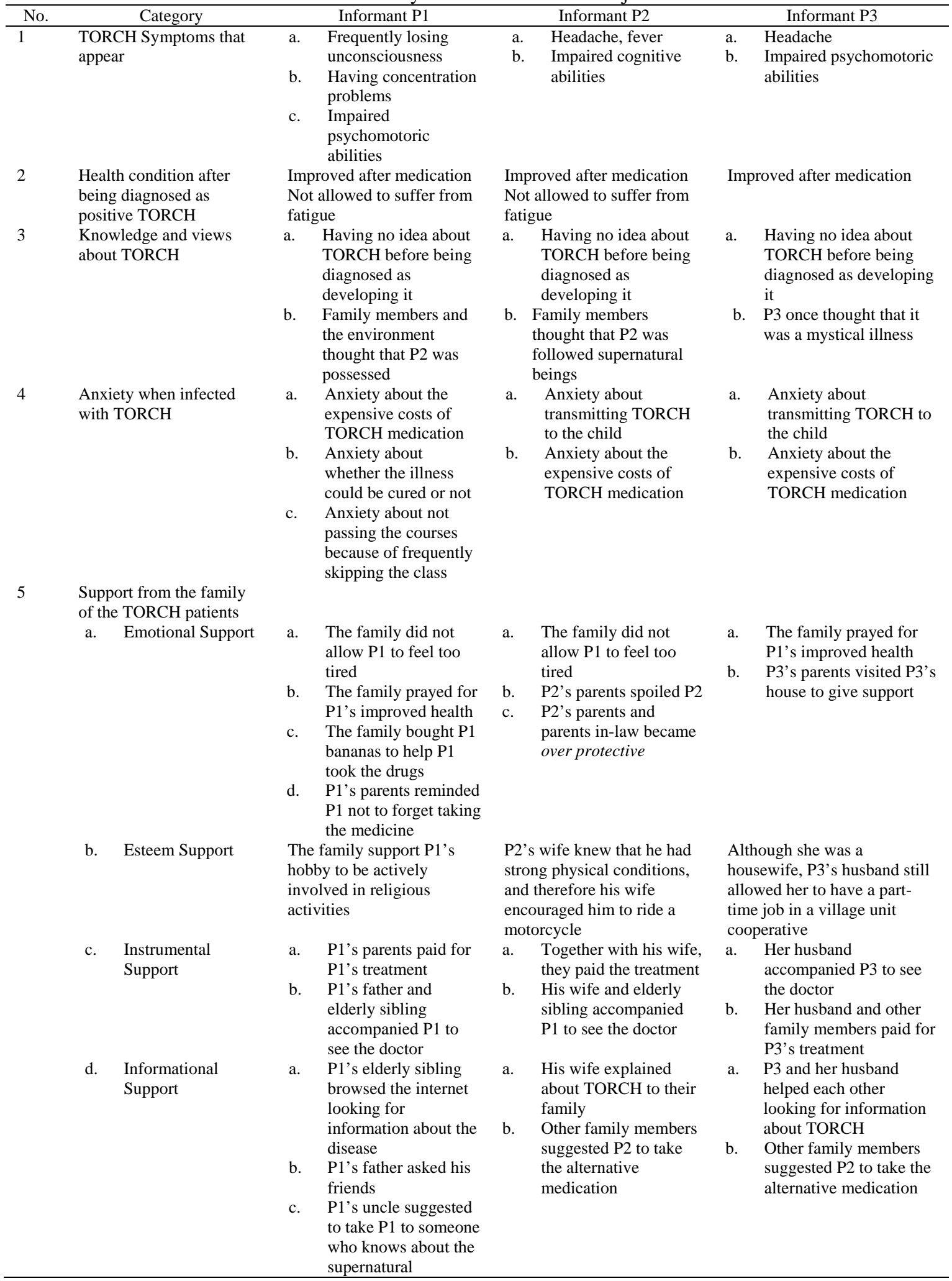

Anxiety is an unpleasant emotional state, involving subjective fear, discomfort in the body and physical symptoms [8], occurring when experiencing frustration and internal conflicts [9], the existence of deep and continuous worry, not having problems judging the reality, personality remains intact, and behavior can be disrupted but still within the normal limits [10]. 
According to the diagnosis of the psychiatrist, the anxiety level of P1 remains in a medium level. P1 still thought about the TORCH treatment that P1 had and took the medicine even though in a lower dosage. Based on the interview that the researcher had with P1, P1 experienced worries over whether the disease that P1 developed could be cured or not, the medical cost, and its academic activities on campus.

"Sure, I feel so sorry for my parents since it costs very much to cure this disease. Because my parents don't have a permanent occupation. So, if I have to ask them to pay a considerable amount of money for the medication every two weeks, I think it will be a great burden for them and that makes me can't stop thinking about it. That's right, it's also stressful.”

P2 did not experience anxiety since he could quickly adapt to his illness and he also obtained full family support from his family so that he did not feel too worried about his illness for a long period of time. However, according to the information provided by P2's wife, he once experienced worries when firstly diagnosed to develop TORCH, especially about the expensive cost to cure this illness. P3 that has married was also worried if the TORCH may infect her infant child.

"P3 just wonder if later this desease will also attack her child or not. And in relation to the medication, if every two weeks I have to spend Rp1,000,000; it means that I have to allocate a budger of Rp2,000,000; in a month. If I continue taking this medication, I'm affraid if I will just waste money on it, so I decide to stop the medication for a while."

Similar to P2, the psychiatrist also diagnosed P2 as not experiencing this sort of anxiety. This is because at the time the psychiatrist examined the anxiety level of P3, she had been already diagnosed as not having TORCH. However, during the period when she was having her TORCH treatment, P3 admitted that she once felt worried, especially if her son might develop the same disease since P3 was giving exclusive breastfeeding at that time and the expensive cost of TORCH medication.

"Of course, I was still breastfeeding at that time, what might happen to my baby? Could my son be infected? Could it be transmitted to my husband through sexual intercourse?”

In addition to the anxiety that the subjects of the research experienced, based on the perspectives of psychiatry and neurology, it is also explained that the anxiety is resulted from the effects of brain damage due to toxoplasma attacks. Based on the triangulation with a neurologist, when a patient is diagnosed with TORCH, his/her psychological condition will change, surprised is the first thing that they will experience. Anxiety grows since the brain experiences cerebritis.

"There are certain parts of the brain that become impaired due to the attacks by this disease, so it seems like the person is developing this disease, psychiatry. Or it might be that the brain is not disturbed but as a result of, what is it, the disease that is not treated properly, excessive anxiety, such complaints might arise, those are quite seimilar, hallucination. "

Toxoplasmosis is acquired during postnatal (after birth), this form is characterized by the existence of takizoit in the blood and other tissues, causing a variety of clinical symptoms, such as cervical lymphadenopathy, fever, headache, as well as psychiatric and neurological complications that can be found in immunocompetent patients [12]. In T. gondii cyst formation, a variety of brain cells, including astrocytes and neurons, can be infected, so that various changes such as anatomy, immunology, pathology, neurotransmitters and gene expression may occur during the brain infection by $T$. gondii. Some of these changes may also play a role in causing various neurological disorders [13].

Many factors influence anxiety, one of which is social support from family [9]. Social support is defined as the presence of others who can be relied on to ask for help, encouragement and acceptance when one experience difficulty [9], and the presence of physical and psychological comfort given by friends or family [11]. Social support also covers verbal and non-verbal information or real assistance given through social familiarity because their presence provides emotional usefulness or behavioral effects for the recipient [11]. It can be concluded that family support is a physically and psychologically comfortable condition that affects and is perceived by an individual from his/ her family environment and the individual will get help and support when she/ he is having trouble.

Types of family support [12]:

1) Emotional support, which is an expression of emphaty, care and attention to an individual so that the individual feels comfortable, loved and cared about.

2) Esteem support, which is an expression of agreement and a positive assessment of ideas, feelings and performance, as well as encouragement to move forward given to an individual in order to establish his/ her confidence when experiencing pressure.

3) Instrumental support, which is direct assistance provided based on what an individual needs, such as providing financial assistance, providing a place to say, or doing certain tasks.

4) Informational support, which is provision of advice, guidance, suggestions or feedback so that an individual can limit the problem and try to find a way out to solve the problem. 
All these three informants gained support from their own family when they became infected with TORCH. The family that lived with the informants became the first to present when the informants were experiencing the symptoms of TORCH and they were always there when the informants were taking TORCH medication. In the case of P3, although this informant did not live at home with its parents, this informant always found the support that it needed.

The presence and support from parents and spouses have a major impact on their health, they could improve and accelerate healing and improve compliance with the rules of the use of drugs [14]. Through all these types of family support that they received, these three informants could go through the periods of TORCH medication that was expensive and took a long time well. Family support makes productivity of the informants which once was disrupted due to TORCH infections becomes normal again, informants' anxiety about things that interfere with their psychological well-being is reduced, and the informants can maintain their physical health although infected with TORCH.

\section{CONCLUSION}

\subsection{Anxiety}

P1 experienced anxiety, while P2 and P3 did not. These three informants were worried since they had to undergo TORCH treatment in the long run in which the prices of the drugs were expensive. These situations made informant P2 stopped its TORCH treatment in the second month of the treatment, while P1 and P2 still had their TORCH treatment. P1 who is a student was worried about not passing the courses as P1 often skipped the class. P2 and P3 are married and each has a child so that they were worried if this TORCH disease might be transmitted to their own child.

\subsection{Family Support}

All these three informants obtained emotional support, esteem support, instrumental support, and informational support from their own family. They all live with their family, such as their parents or parents in-laws, their husband or wife, their child, their siblings, and their other relatives.

The researcher offers a number of suggestions with respect to anxiety and family support for patients infected with TORCH, namely:

a. For TORCH patients who experience anxiety, they are expected to find out more about TORCH and consult medical or paramedical personnel in order that their anxiety does not make their psychological well-beings disturbed.

b. For TORCH patients, they are expected to ask for more family support for their treatment and recovery. Several things that can be done include:

1) Increasing the frequency of communication and telling about their health improvement.

2) Taking family members to take turns accompanying their treatment and meeting the doctor who examines them.

3) Explaining and discussing the medical cost so that it will not be a burden during the healing process.

c. For health observers (health workers, students and the community), this research is expected to make a public health promotion program that can increase knowledge about mental health and TORCH. Several things that can be done are:

1) Education on the epidemiology, effects as well as preventive and curative measures and rehabilitation of TORCH.

2) Increasing the marketing of healthy and halal meat consumption through better regulation and supervision.

3) Organizing health examination programs and mental health tests on a regular basis aimed at high school students, college students, employees, or communities with a high risk for anxiety or TORCH.

4) Public service announcements on anxiety family support and TORCH on television or social media. Television and social media are very powerful media for information dissemination.

d. For further research, comparative studies with more subjects are expected to conduct, which consist of newly-diagnosed with TORCH patients, TORCH patients who are pregnant or have given birth recently, or subjects with other characteristics that currently undergo TORCH treatment. 


\section{REFERENCES}

[1] Soedarmo, SSP., Gamma H., Hadinegoro, SRS., Safari, HI., "Buku Ajar Infeksi \& Pediatri Tropis”, Edisi Kedua, Badan Penerbit IDAI, Jakarta, pp.122-127; 143-154; 276-291; 458-465, 2012.

[2] Kalyanamitra, "TORCH Waspadai Bahaya dan Infeksinya”, www.kalyanamitra.or.id, downloaded on March 4, 2014, Yogyakarta.

[3] Zainurrofikoh, "Peran Dukungan Sosial Pasangan dan Optimisme Terhadap Kesejahteraan Psikologis Penderita Infeksi TORCH”, Tesis, Pascasarjana, Universitas Gadjah Mada, Yogyakarta, pp.1-13, 2008.

[4] Sunberg, ND., Winebarger, AA., Taplin, JR., “Psikologi Klinis Perkembangan Teori, Praktik, dan Penelitian”, Edisi Keempat, Pustaka Pelajar, Yogyakarta, pp.321-355, 2007.

[5] Rahmat, PS., “Penelitian Kualitatif”, Equilibrium, vol/issue: 5(9), pp.1-8, January-June 2009.

[6] Moleong, LJ., “Metodologi Penelitian Kualitatif”, Edisi Revisi, PT Remaja Rosdakarya, Bandung, pp.1-344, 2010.

[7] Tiurmauly, V., "Kecemasan Terhadap Kematian pada Remaja dengan HIV/AIDS”, Skripsi, Universitas Indonesia, Depok, pp.26-33, 2007.

[8] Katona, C., Cooper, C., Robertson, M., “At a GlancePsikiatri”, Edisi Keempat, Penerbit Erlangga, pp. 26-29, 2008.

[9] Kusumawardani, D., "Kecemasan pada Wanita Pasca Menopause Ditinjau dari Dukungan Sosial Suami”, Skripsi, Universitas Katolik Soegijapranata, Semarang, pp.16-19, 2007.

[10] Hawari, D., “Manajemen Stres Cemas dan Depresi”, Balai Penerbit FKUI, Jakarta, pp.63-78, 2011.

[11] Hendrayanti, N., "Hubungan Antara Dukungan Sosial Keluarga dengan Kecemasan Terhadap Penerimaan Sosial pada Warga Binaan Lembaga Permasyarakatan Anak Kutoarjo”, Skripsi, Universitas Ahmad Dahlan, Yogyakarta, pp.13-15, 2012.

[12] Shirbazou, S., Abasian, L., Meymand, FT., "Effects of Toxoplasma gondii Infection on Plasma Testosterone and Cortisol Level and Stress Index on Patients Referred to Sina Hospital, Tehran”, Jundishapur J Microbiol, vol/issue: 4(3), pp.167-173, January 2011.

[13] Dalimi, A., Abdoli, A., "Latent Toxoplasmosis and Human”, Iranian J Parasitol, vol/issue: 7(1), pp.1-17, January 2012.

[14] Sunberg, ND., Winebarger, AA., Taplin, JR., “Psikologi Klinis Perkembangan Teori, Praktik, dan Penelitian”, Edisi Keempat, Pustaka Pelajar, Yogyakarta, pp.321-355, 2007. 